\title{
Age, allocation and availability of nonstructural carbon in mature red maple trees
}

\author{
Mariah S. Carbone ${ }^{1,2}$, Claudia I. Czimczik ${ }^{3}$, Trevor F. Keenan ${ }^{1}$, Paula F. Murakami ${ }^{4}$, Neil Pederson ${ }^{5}$, \\ Paul G. Schaberg ${ }^{4}$, Xiaomei Xu ${ }^{1}$ and Andrew D. Richardson ${ }^{1}$
}

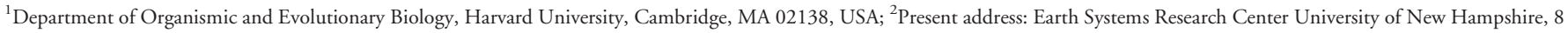

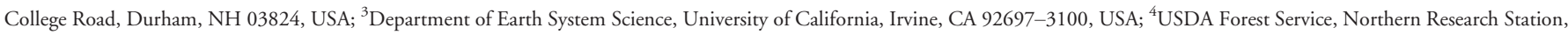
Burlington, VT 05405, USA; ${ }^{5}$ Tree Ring Laboratory, Lamont-Doherty Earth Observatory, Palisades, NY 10964, USA

Author for correspondence: Mariah S. Carbone Tel: +1 6038687654

Email: mariah.carbone@unh.edu

Received: 29 May 2013

Accepted: 14 July 2013

New Phytologist (2013)

doi: $10.1111 /$ nph.12448

Key words: ${ }^{13} \mathrm{C}$, Acer rubrum (red maple), carbohydrates, radiocarbon $\left({ }^{14} \mathrm{C}\right)$, ring growth, sprouts, stem respiration, storage, stump.

\section{Summary}

- The allocation of nonstructural carbon (NSC) to growth, metabolism and storage remains poorly understood, but is critical for the prediction of stress tolerance and mortality.

- We used the radiocarbon $\left({ }^{14} \mathrm{C}\right)$ 'bomb spike' as a tracer of substrate and age of carbon in stemwood NSC, $\mathrm{CO}_{2}$ emitted by stems, tree ring cellulose and stump sprouts regenerated following harvesting in mature red maple trees. We addressed the following questions: which factors influence the age of stemwood NSC?; to what extent is stored vs new NSC used for metabolism and growth?; and, is older, stored NSC available for use?

- The mean age of extracted stemwood NSC was $10 \mathrm{yr}$. More vigorous trees had both larger and younger stemwood NSC pools. NSC used to support metabolism (stem $\mathrm{CO}_{2}$ ) was 1-2 yr old in spring before leaves emerged, but reflected current-year photosynthetic products in late summer. The tree ring cellulose ${ }^{14} \mathrm{C}$ age was $0.9 \mathrm{yr}$ older than direct ring counts. Stump sprouts were formed from NSC up to $17 \mathrm{yr}$ old.

- Thus, younger NSC is preferentially used for growth and day-to-day metabolic demands. More recently stored NSC contributes to annual ring growth and metabolism in the dormant season, yet decade-old and older NSC is accessible for regrowth.

\section{Introduction}

Nonstructural carbon (NSC) compounds are the primary products of photosynthesis, consisting mainly of mobile sugars (e.g. sucrose, glucose, fructose) and immobile starch and lipids. Once assimilated, NSC may be allocated to metabolism or new tissue growth, exported to the soil through roots, used to produce protective compounds or stored for future use (Chapin et al., 1990; Herms \& Mattson, 1992). Stored NSC provides an essential carbon $(\mathrm{C})$ buffer to plants when demand (growth, protection and metabolism) exceeds supply (photosynthesis), such as during the night, the dormant season or in response to environmental stress or disturbance. However, allocation to and from storage, and the accessibility and function of stored NSC, still remain poorly understood within long-lived plants (Sala et al., 2012).

Mature trees contain large amounts of NSC (Körner, 2003), several times that needed to regrow the canopy foliage (Hoch et al., 2003; Würth et al., 2005). Allocation of NSC to storage has traditionally been thought of as a passive process, in which NSC is allocated to the storage pool only after all other demands for C have been met (Chapin et al., 1990). However, NSC storage may also be an active process, in which NSC is allocated at the expense of growth (Wiley \& Helliker, 2012), presumably as an evolutionary adaptation to cope with stress factors, such as variable climate, pests and disease, or disturbance. In addition to serving as a large buffer pool of C, NSC may also support important reserves of mobile nitrogen (Millard \& Grelet, 2010) and may help to maintain hydraulic conductivity during drought and freeze-thaw events (Sala et al., 2012). Thus, an understanding of NSC dynamics is important for the prediction of tree stress responses, mortality and resilience to global change.

Previous work has indicated that NSC allocated to metabolism and growth can come from newer (recently photosynthesized) or older (stored) sources. Ecosystem-scale pulse-labeling studies have shown that the majority of new NSC is respired in days (Carbone et al., 2007; Högberg et al., 2008; see review by Epron et al., 2012 and references therein), demonstrating a fast link between assimilation, allocation and metabolism, with rapid use of new NSC even in belowground processes. NSC allocated to foliage and fruits also appears to be from newly assimilated NSC (Keel et al., 2006; Hoch et al., 2013). However, there is also evidence that NSC allocated to root (Czimczik et al., 2006; Schuur \& Trumbore, 2006; Carbone et al., 2011) and stem (Muhr et al., 2013) respiration can be several years old, reflecting a significant 
contribution of stored NSC. New roots, leaf buds and flowers have also been shown to grow from stored NSC up to $2 \mathrm{yr}$ old (Gaudinski et al., 2009; Ichie et al. 2013). In tree rings, stored NSC up to 3 or 4 yr old has been incorporated into tree ring cellulose growth (Keel et al., 2006; Krepkowski et al., 2013).

More recently, evidence has been obtained that much older NSC is present in mature trees. Richardson et al. (2013) found that the NSC extracted from the stemwood of temperate forest trees was $7-14 \mathrm{yr}$ old. Yet, the availability of this decade-old NSC to support the growth and metabolism of these trees is not known (Rocha, 2013). NSC accumulated in woody tissues may become sequestered, and therefore not available to the tree for future use (Millard et al., 2007). However, Vargas et al. (2009) demonstrated that NSC as old as $10 \mathrm{yr}$ was allocated to new root growth following a major hurricane disturbance in a dry tropical forest, proving that some older NSC may still be accessible.

Collectively, these results suggest that trees have both fast and slower cycling NSC pools (Carbone \& Trumbore, 2007; Kuptz et al., 2011; Richardson et al., 2013). There is also evidence for mixing between these components (Keel et al., 2006, 2007), and fast and slow pools probably have different ecological and $\mathrm{C}$-cycling roles that have not been characterized fully. Hence, the identification of the factors controlling the amount and residence time of NSC within trees, the allocation of new vs stored NSC to different processes and the accessibility of stored NSC is needed to improve storage and allocation representations in current C-cycling models.

To better understand these aspects of NSC allocation and storage, we studied mature red maple (Acer rubrum) trees in two New England, USA temperate forests. Applying the radiocarbon $\left({ }^{14} \mathrm{C}\right)$ 'bomb spike' approach (Trumbore, 2006), we estimated the age (a proxy for the mean residence time, MRT) of $\mathrm{C}$ in stemwood NSC, stem $\mathrm{CO}_{2}$ emissions, tree ring cellulose and stump sprouts regenerated following harvesting. The main goal of our research was to use these isotopic measurements, together with stemwood NSC concentrations, to compare the NSC used for day-to-day metabolism, annual wood growth and regrowth to the NSC actually present in the stemwood. Specifically, we addressed three questions. First, how does the age of stored NSC vary with tree size, tree age, and growth and respiration rates? Second, what is the age of NSC allocated to stem respiration and wood growth? Finally, is decade-old NSC accessible to trees?

\section{Materials and Methods}

The work was conducted between 2011 and 2012 in two New England, USA mixed hardwood forests. Harvard Forest $\left(42.53^{\circ} \mathrm{N}, 72.17^{\circ} \mathrm{W}, 340 \mathrm{~m}\right.$ above sea level) is located in central Massachusetts and has a mean annual temperature of $8.2^{\circ} \mathrm{C}$ and a mean annual precipitation of $1270 \mathrm{~mm}$. Approximately $250 \mathrm{~km}$ to the northeast, Bartlett Experimental Forest $\left(44.06^{\circ} \mathrm{N}\right.$, $71.29^{\circ} \mathrm{W}, 270 \mathrm{~m}$ above sea level) is located in the White Mountain National Forest, New Hampshire. Bartlett Experimental Forest is slightly cooler, with a mean annual temperature of $7.3^{\circ} \mathrm{C}$, but, at $1270 \mathrm{~mm}$, the mean annual precipitation is the same as at Harvard Forest. Red maple (Acer rubrum L.) is a dominant tree species at both sites. It is considered as a generalist species (Abrams, 1998) that grows throughout the eastern USA from Maine to Florida.

\section{Stem $\mathrm{CO}_{2}$ emissions}

At each site, we selected five red maple trees, ranging in size from 9 to $34 \mathrm{~cm}$ diameter at breast height ( $\mathrm{DBH} ; 1.4 \mathrm{~m}$ above ground level; Table 1). Static chambers (volume, $2.93 \mathrm{l}$ ) were installed to measure the stem $\mathrm{CO}_{2}$ flux and to collect $\mathrm{CO}_{2}$ for ${ }^{14} \mathrm{C}$ analyses. Each chamber was constructed from a plastic polypropylene pipe T-fitting permanently capped on the top and bottom ends. For opening and closing the chamber, a threaded cap with an O-ring seal was screwed on to the outer side of the $\mathrm{T}$. On the inner side, there was a $256-\mathrm{cm}^{2}$ rectangular opening in direct contact with the tree stem. Chambers were attached to the stem at breast height using a hot glue gun, and then sealed to the stem surface with caulking (Nautiflex; OASE GmbH, OerelBarchel, Germany). While not in use, a cap with a fine wire mesh screen was screwed on to the $T$, so that chambers remained open to the ambient atmosphere, but were closed to insects and birds.

Before sampling for ${ }^{14} \mathrm{C}$, stem $\mathrm{CO}_{2}$ flux rates were measured on each chamber. The chamber was closed with a threaded screw cap containing gas inlet and outlet ports, as well as a probe for measuring air temperature inside the chamber. Air was circulated with a pump at $0.51 \mathrm{~min}^{-1}$ within the chamber headspace through an infrared gas analyzer (IRGA, LI-820; Licor, Lincoln, $\mathrm{NE}, \mathrm{USA}$ ) for $5 \mathrm{~min}$. We recorded the change in $\mathrm{CO}_{2}$ concentration every $1 \mathrm{~s}$, and then fitted a linear model using least-squares regression to determine the rate of $\mathrm{CO}_{2}$ accumulation. The slope of the fitted equation, the chamber volume and the tree stem surface area covered by the chamber were used to calculate the stem $\mathrm{CO}_{2}$ flux rate $\left(\mu \mathrm{mol} \mathrm{CO} \mathrm{Cm}^{-2} \mathrm{~s}^{-1}\right)$. Molar fluxes were based on concentrations adjusted for temperature and atmospheric pressure.

To collect samples for the ${ }^{14} \mathrm{C}$ content of stem $\mathrm{CO}_{2}$ emissions, the chambers were closed using a threaded screw cap containing gas inlet and outlet ports, and the chambers were left to accumulate $\mathrm{CO}_{2}$ for $7 \mathrm{~d}$. At this time, $\mathrm{CO}_{2}$ concentrations in each chamber were measured with the IRGA, and samples were extracted through the outlet port with pre-evacuated air canisters (X3 series; LabCommerce Inc., San Jose, CA, USA). To keep pressure at ambient levels, a soda lime column was attached to the inlet port of each chamber, allowing $\mathrm{CO}_{2}$-free air to pass into the chamber whilst the samples were extracted. At each site, an atmospheric air sample was taken at chamber height with a pre-evacuated 6-1 canister that filled slowly over $2 \mathrm{~h}$. These air samples were used to correct the reported ${ }^{14} \mathrm{CO}_{2}$ emitted from the stem for the air remaining in the chambers when the $\mathrm{CO}_{2}$ accumulation began using a two-end-member mixing model. Stem $\mathrm{CO}_{2}$ flux measurements and sampling for ${ }^{14} \mathrm{CO}_{2}$ analysis were conducted in the field on two different occasions in 2012: early spring before leaf-out (mid-April) and late summer (beginning of September). We interpret these measurements as a proxy for stem respiration, even though $\mathrm{CO}_{2}$ emitted from the stem may 
integrate both root and stem respiration sources (Bloemen et al., 2013; Trumbore et al., 2013).

\section{Stemwood NSC and tree ring cellulose}

Two shallow stemwood cores were collected from each tree with a standard 4.3-mm increment borer (Häglof Company Group, Långsele, Sweden) at the same height as the chambers in September 2011. Cores were placed in clean plastic drinking straws and immediately frozen in the field on dry ice. On return to the laboratory, the cores were dried and the outer $2 \mathrm{~cm}$ of each core were isolated. One core was used for total NSC concentration analyses and the other for ${ }^{14} \mathrm{C}$ analyses.

The NSC concentration analysis was conducted at the USDA Forest Service in Burlington, VT, USA following the methods of Wong et al. (2003). Briefly, ethanol-soluble fractions were analyzed for sucrose, glucose, fructose, raffinose and stachyose using a Waters Alliance HPLC system (Milford, MA, USA). Sugars were detected with a Waters 2414 refractive index detector and Waters PC-based Empower software. The separated soluble sugars were identified and quantified with known standards and converted to $\mathrm{mg} \mathrm{sugar} \mathrm{g}^{-1}$ oven-dry wood. The ethanol-insoluble pellets were used to determine starch content after gelatinization with $0.1 \mathrm{M} \mathrm{KOH}$ and neutralization with acetic acid by hydrolysis with amyloglucosidase (Wargo et al., 2002). Glucose formed by hydrolysis was determined with a glucose hexokinase kit (Pointe Scientific, Canton, MI, USA) at $340 \mathrm{~nm}$ with a Bio-Tek Instruments Elx800 UV microplate reader (Winooski, VT, USA). Concentrations of starches were calculated from glucose standard curves and expressed as $\mathrm{mg}$ starch $\mathrm{g}^{-1}$ oven-dry wood.

For ${ }^{14} \mathrm{C}$ analyses, soluble NSC (total sugars) was extracted from each core sample by hot water extraction, as described in Richardson et al. (2013). Other existing extraction methods using ethanol or methanol, such as developed by Wong et al. (2003), cannot be applied to isolate NSC for ${ }^{14} \mathrm{C}$ analysis because they introduce too much extraneous $\mathrm{C}$ that alters the ${ }^{14} \mathrm{C}$ content of the NSC pool. Previous work established very good agreement between NSC concentrations and the yield of extracted sugars for the ${ }^{14} \mathrm{C}$ protocol (Richardson et al., 2013). In addition, only sugar and not starch was extracted for ${ }^{14} \mathrm{C}$ analysis because of the previously established correspondence between ${ }^{14} \mathrm{C}$ of starch and sugar pools (Richardson et al., 2013) and the time and expense associated with ${ }^{14} \mathrm{C}$ measurements.

The innermost ring (i.e. oldest) in each 2-cm stemwood core was isolated for ${ }^{14} \mathrm{C}$ analyses. Holocellulose was extracted using a traditional batch processing cellulose extraction method, based on the work of Leavitt \& Danzer (1993). Samples sealed in Ankom $^{\text {TM }}$ (Macedon, NY, USA) F57 Dacron filter bags were placed in a $50-\mathrm{mm}$-ID $(200 \mathrm{ml})$ Soxhlet apparatus and extracted with $600 \mathrm{ml}$ of a 2:1 mixture of toluene and ethanol, and then with $600 \mathrm{ml}$ ethanol, each for c. $24 \mathrm{~h}$. After the solvent extraction, samples were boiled gently for $2 \mathrm{~h}$ in Milli-Q water and then placed in a bleaching solution ( $4 \mathrm{~g}$ of sodium chlorite and $2 \mathrm{ml}$ of glacial acetic acid added to $600 \mathrm{ml}$ of water) at $70^{\circ} \mathrm{C}$. An additional $4 \mathrm{~g}$ of chlorite and $2 \mathrm{ml}$ of acetic acid were added after 3-4h, after which the samples were washed several times with Milli-Q water over $3-4 \mathrm{~h}$ and dried at $60^{\circ} \mathrm{C}$ overnight.

\section{Tree ages and growth rates}

Trees were also cored to the pith in September 2011 with an increment borer at the same height as the shallower NSC cores to determine tree age and growth rates. These cores were mounted in grooved wooden blocks and sanded. Annual xylem increments were microscopically measured to a resolution of $0.001 \mathrm{~mm}$ using a Velmex sliding stage unit (Velmex Inc., Bloomfield, NY, USA) with MeasureJ2X software (VoorTech Consulting, Holderness, NH, USA) according to the methods of Stokes \& Smiley (1968). The computer program COFECHA was used to detect potential cross-dating errors in ring series (Holmes, 1983). We converted ring width data to basal area increments $\left(\mathrm{cm}^{2} \mathrm{yr}^{-1}\right)$ assuming a circular outline of stem cross-sections. In addition to the total number of rings in the core, we counted the number of rings in the outer $2 \mathrm{~cm}$ of stemwood, corresponding to the tissue used for NSC and sugar ${ }^{14} \mathrm{C}$ analyses.

\section{Stump sprouts}

After timber harvesting, red maple is characteristically a prolific stump sprouter. To obtain stump sprouts, which are formed from NSC stored in the still-living root system, we took advantage of harvest activities that occurred at each site during the late autumn and winter of 2010-2011. Shortly after snowmelt in 2011, we identified c. 15 red maple stumps at each site. Stumps ranged greatly in size from 3.7 to $66 \mathrm{~cm}$ in basal diameter. Each stump was partially covered with thick black plastic to completely block photosynthetically active radiation. Thus, when the sprouts emerged beneath the plastic in the spring, they could not incorporate any new $\mathrm{C}$ through photosynthesis. Between April and May, each stump was checked every 2-7 d for sprouts underneath the plastic. Any sprouts that were present were collected and immediately air dried. Sprouts ranged in size from 1 to $3 \mathrm{~cm}$ in length. To determine the age of the tree from which each sprout was collected, we cut disks from each stump with a chain saw. These were air dried and then planed smooth with an electric hand planer before counting rings under a dissecting microscope.

\section{Isotope analyses}

For isotopic analysis of the $\mathrm{C}$ in stump sprouts, tree ring cellulose, annual plants (to be described) and extracted sugars, these samples were first combusted to $\mathrm{CO}_{2}$. The combusted samples, as well as the samples already in the gas phase (ambient air and stem $\mathrm{CO}_{2}$ emissions), were then purified on a vacuum line and converted to graphite (Xu et al., 2007). Aliquots of $\mathrm{CO}_{2}$ were extracted from each sample for $\delta^{13} \mathrm{C}$ measurement on a Thermo Electron Gas Bench II coupled with a Delta Plus Isotope Ratio Mass Spectrometer (Thermo Finnigan, Bremen, Germany). Graphite was analyzed for its ${ }^{14} \mathrm{C}$ content at the W.M. Keck Carbon Cycle Accelerator Mass Spectrometry facility at UC Irvine (KCCAMS; Southon et al., 2004). Data are reported in Fraction 
Modern $\left(\mathrm{F}^{14} \mathrm{C}\right)$, the ratio of ${ }^{14} \mathrm{C} /{ }^{12} \mathrm{C}$ in a sample divided by that of a standard of fixed isotopic composition (0.95 times the ${ }^{14} \mathrm{C} /{ }^{12} \mathrm{C}$ of oxalic acid I standard from the year 1950; Reimer et al., 2004). Measurements have been corrected for the effects of mass-dependent isotope fractionation by normalizing to a common $\delta^{13} \mathrm{C}$ value $\left(-25 \%\right.$ ) and assuming that ${ }^{14} \mathrm{C}$ is fractionated twice as much as ${ }^{13} \mathrm{C}$ (Stuiver \& Polach, 1977). The measurement precision $( \pm 1 S D)$ for all $\mathrm{F}^{14} \mathrm{C}$ is $\leq 0.0024$ and for $\delta^{13} \mathrm{C}$ values is $\leq 0.15 \%$.

\section{Determination of ${ }^{14} \mathrm{C}$-based ages}

The mean age of $\mathrm{C}$ in the sugars, stump sprouts and $\mathrm{CO}_{2}$ emitted by stems was determined using the ${ }^{14} \mathrm{C}$ 'bomb spike' approach, with ages estimated by direct comparison with the northern hemisphere atmospheric ${ }^{14} \mathrm{CO}_{2}$ record (Levin et al., 2008; X. Xu, unpublished). Using this approach, the ${ }^{14} \mathrm{C}$ age is an accurate estimate of the MRT of C pools $20 \mathrm{yr}$ old and younger (assuming they are well mixed; Richardson et al., 2013). We monitored for local offsets in this record with air and annual plant samples (grown in non-forested areas: jewelweed, Impatiens capensis Meerb.; ragweed, Ambrosia artemisiifolia L.; Japanese stilt grass, Microstegium vimineum Trin.) that were collected at each site (and processed for ${ }^{14} \mathrm{C}$ as described previously) to quantify the site-specific background atmospheric ${ }^{14} \mathrm{CO}_{2}$, and used as the signature of photosynthetic products at the time of sampling. For 2011, the background values were 1.0444 and 1.0488 at Harvard Forest and Bartlett Experimental Forest, respectively, and, in 2012, they were 1.0372 and 1.0403 , respectively. Because samples were collected over $2 \mathrm{yr}$ (atmospheric ${ }^{14} \mathrm{CO}_{2}$ is declining with time), when plotting multi-year data together, we report the difference between the sample $\mathrm{F}^{14} \mathrm{C}$ and the atmosphere $\mathrm{F}^{14} \mathrm{C}$ at the time each sample was collected (Fig. 1). Finally, tree one at Harvard Forest was eliminated from the final ${ }^{14} \mathrm{C}$ results and analyses because the tree ring cellulose $\mathrm{F}^{14} \mathrm{C}$ indicated the presence of pre-bomb C (i.e. 1954 or earlier), and therefore it was not possible to determine a ${ }^{14} \mathrm{C}$-based age.

\section{Data analyses}

We used principal component analysis (PCA) to identify the major axes of variation in our multivariate dataset (tree age, $\mathrm{DBH}$, mean basal area increment, total NSC concentration, stem $\mathrm{CO}_{2}$ flux rate and sugar age). PCA is a widely used data reduction technique in which new composite variables (components) are constructed as linear combinations of the original independent variables. It is particularly appropriate when there is a high degree of correlation among the independent variables. The first few components can typically explain much of the variability in the original dataset. Our PCA was conducted in MATLAB (function pca; MathWorks, Natick, MA, USA) on the correlation matrix, because units differed among variables (McGarigal et al., 2000).

To investigate how patterns of tree growth were related to NSC concentration and age, we combined data from this study with data from an additional 27 red maple trees sampled in 2010 (nine each at Harvard Forest and Bartlett Experimental Forest, and an additional nine at Howland Forest, Maine) and reported in Richardson et al. (2013). We used an autocorrelation analysis (function autocorr; MATLAB) of the last $50 \mathrm{yr}$ of ring width chronology for each tree to quantify the inherent 'memory' in the annual growth increment - that is, how well was growth in year $t$ correlated with lagged growth in years $t-1, t-2, t-3 \ldots$ ? For each tree, we identified the maximum lag (in years) that was significant (at 95\% confidence) in the ring width autocorrelation function. We conducted this analysis on residuals of raw ring width detrended with an inflexible spline (1-2 piece, second- and third-order polynomial, robust smoothing; Garcia, 2010) to remove tree size and age-related trends associated with tree growth (Fritts, 1976).

\section{Results}

\section{Stemwood NSC and tree ring cellulose}

Across all trees, the concentrations of total stemwood NSC averaged $18.6 \pm 4.7 \mathrm{mg} \mathrm{g}^{-1}$ oven-dry wood (total = starch + sugars, mean $\pm 1 \mathrm{SD}$; Table 1). Sugars averaged $4.5 \pm 1.2 \mathrm{mg} \mathrm{g}^{-1}$, contributing $11-32 \%$ of the extracted total stemwood NSC across the different trees, with a mean of $c .24 \%$. Tree DBH and height were positively correlated with total stemwood NSC concentration $(r=0.71, P=0.02$ and $r=0.67, P=0.03$, respectively; Table 1) and sugar $\delta^{13} \mathrm{C}(r=0.70, P=0.03$ and $r=0.61$, $P=0.06$, respectively; Table 2). Sugar $\mathrm{F}^{14} \mathrm{C}$ was similar at Harvard Forest and Bartlett Experimental Forest, $1.0851 \pm 0.0182$ and $1.0900 \pm 0.0297$, corresponding to ${ }^{14} \mathrm{C}$ ages of $9.3 \pm 3.5$ and $10.3 \pm 5.9 \mathrm{yr}$, respectively (Fig. 1 ; Table 2). Sugar ${ }^{14} \mathrm{C}$ age was positively correlated with the number of rings in the $2-\mathrm{cm}$ core from which the NSC was extracted $(r=0.84, P<0.01$; Fig. 2a). Using the relationship between sugar ${ }^{14} \mathrm{C}$ age and starch ${ }^{14} \mathrm{C}$ age established in Richardson et al. (2013) for red maple, the estimated concentration-weighted mean ${ }^{14} \mathrm{C}$ age of total NSC across all trees was $9.1 \pm 7.8 \mathrm{yr}$.

The age of the cellulose in the innermost ring (oldest) of the 2-cm cores, determined by ${ }^{14} \mathrm{C}$ analyses, and the age of the cellulose determined by visually counting the number of rings in the $2-\mathrm{cm}$ cores were extremely similar (Fig. 2b). For three of the trees, the difference between the two measurements fell within the uncertainty of the tree ring cellulose ${ }^{14} \mathrm{C}$ measurement error $( \pm 1 \mathrm{yr})$. Across all cores, the tree ring cellulose ${ }^{14} \mathrm{C}$ age was $0.9 \pm 1.8 \mathrm{yr}$ older (mean $\pm 1 \mathrm{SD}$ ) than the number of rings in the 2 -cm core. Interestingly, the difference between the two measurements was positively related to the extracted sugar ${ }^{14} \mathrm{C}$ age from the stemwood $(r=0.60, P=0.08)$, indicating that the age of NSC allocated to ring growth reflects that of the stemwood NSC pool to some degree.

\section{Stem $\mathrm{CO}_{2}$ emissions}

In early spring (April), before leaf-out, the average stem $\mathrm{CO}_{2}$ flux rate across all trees was $0.44 \pm 0.28 \mu \mathrm{mol} \mathrm{CO}_{2} \mathrm{~m}^{-2} \mathrm{~s}^{-1}$ $($ mean $\pm 1 S D)$ at a mean chamber air temperature of $10^{\circ} \mathrm{C}$ (Table 1). In the late summer (September), the average rate was 


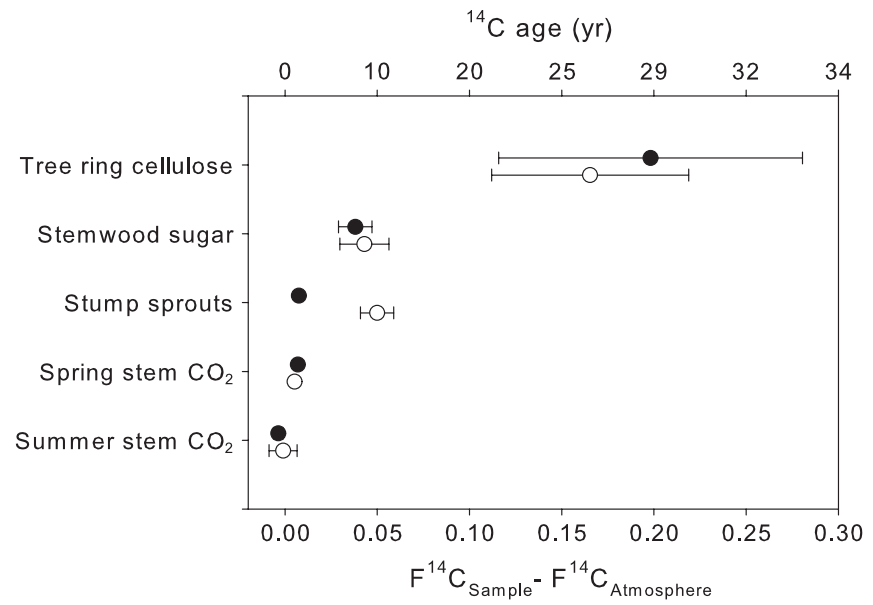

Fig. 1 Difference between the ${ }^{14} \mathrm{C}$ of samples and ${ }^{14} \mathrm{C}$ of the atmosphere at the time at which each sample was collected (in Fraction Modern) on the bottom $x$ axis, for cellulose in the innermost (oldest) ring of the 2$\mathrm{cm}$-deep stemwood core, extracted stemwood sugars, stump sprouts (yr) on the top $x$ axis. Symbols and error bars represent the mean $\pm 1 S D$ of $(n=4)$ red maple (Acer rubrum) trees at Harvard Forest (closed circles) and $(n=5)$ trees at Bartlett Experimental Forest (open circles), both sites located in New England, USA. In some cases, the error is smaller than the size of the symbol.

$0.94 \pm 0.44 \mu \mathrm{mol} \mathrm{CO} \mathrm{Cm}^{-2} \mathrm{~s}^{-1}$ at $22^{\circ} \mathrm{C}$. This corresponds to a seasonal $\mathrm{Q}_{10}$ temperature sensitivity of $c$. 2. Spring stem $\mathrm{F}^{14} \mathrm{CO}_{2}$ was higher $(P=0.06$ by paired $t$-test $)$ than that of late summer, $1.0447 \pm 0.0042$ and $1.0369 \pm 0.0122$, respectively (Fig. 1, Table 2). This corresponded to a ${ }^{14} \mathrm{C}$ age of $1.5 \pm 1.0 \mathrm{yr}$ in spring and, in summer, it reflected the current-year photosynthetic products with the exception of one tree (Bartlett-5). This tree emitted 3.4-yr-old $\mathrm{C}$ in spring and 7.3-yr-old $\mathrm{C}$ in summer. In addition, stem-emitted $\delta^{13} \mathrm{CO}_{2}$ was more negative ( $P=0.07$ by paired $t$-test) in spring than in late summer, $-25.2 \pm 1.8 \%$ and $-24.1 \pm 1.3 \%$, respectively (Table 2 ). In both spring $(r=0.77, P=0.01)$ and late summer $(r=0.65$, $P=0.05)$, stem-emitted $\delta^{13} \mathrm{CO}_{2}$ was positively correlated with the stemwood sugar $\delta^{13} \mathrm{C}$ extracted in late summer of the previous year. By contrast, there was no significant correlation (both $P>0.1$ ) between stemwood sugar $\mathrm{F}^{14} \mathrm{C}$ and stem-emitted $\mathrm{F}^{14} \mathrm{CO}_{2}$ in either spring or summer.

\section{Tree characteristics and NSC}

The PCA shows how tree characteristics, such as size, age and growth rate, co-vary with stemwood NSC concentration, stemwood sugar age and stem $\mathrm{CO}_{2}$ flux (Fig. 3). The dataset passed the Kaiser-Meyer-Olkin sampling adequacy test (0.73), as well as Bartlett's test of sphericity $\left(\chi^{2}=35.0, P<0.01\right)$. Component 1 explained $70 \%$ of the total variance in the dataset, and is interpreted as a general indicator of tree vigor. Trees with positive scores on component 1 were faster growing and larger in size, and had higher stemwood NSC concentrations, greater stem $\mathrm{CO}_{2}$ flux rates and younger stemwood sugars $(6 \pm 4 \mathrm{yr}$ for trees with component $1>0$, compared with $14 \pm 4 \mathrm{yr}$ for trees with component $1<0$ ). Tree age was not a major factor on and stem $\mathrm{CO}_{2}$ emitted in spring and summer. Corresponding ${ }^{14} \mathrm{C}$ age

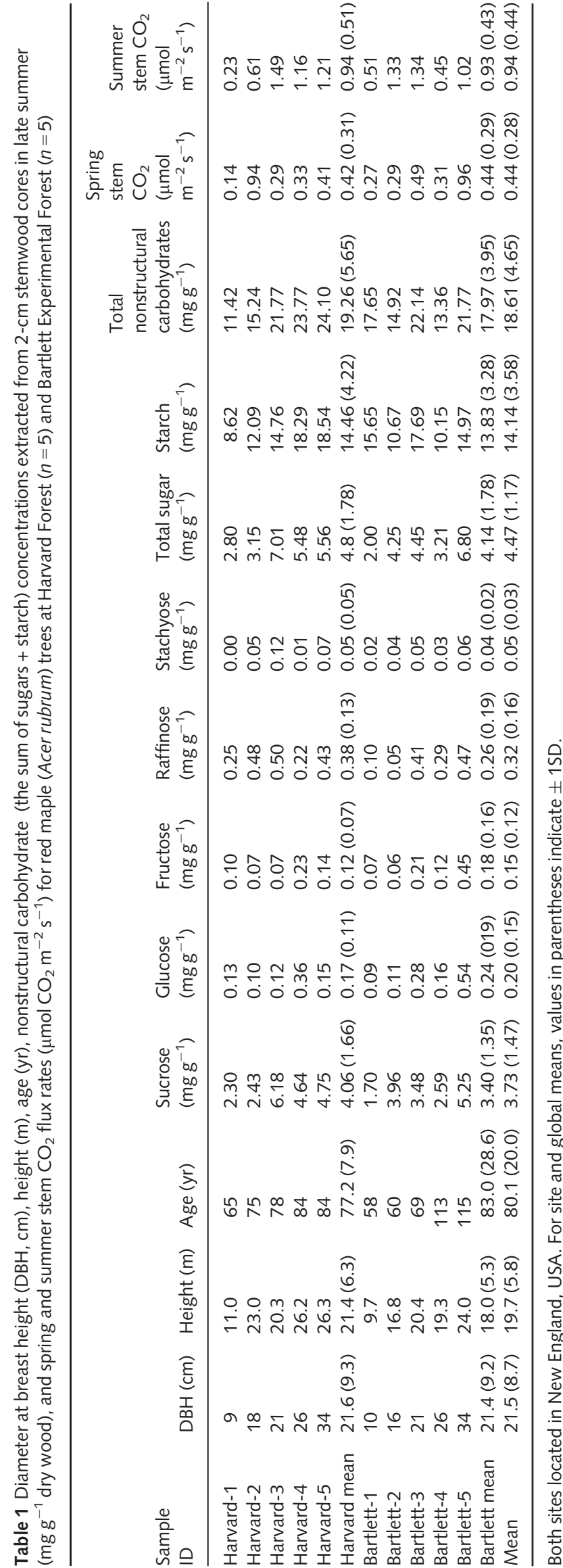


Table 2 The $\mathrm{F}^{14} \mathrm{C}$ (in Fraction Modern) and $\delta^{13} \mathrm{C}(\%)$ of cellulose extracted from the innermost (oldest) ring in the 2-cm stemwood core, extracted stemwood sugars, and stem $\mathrm{CO}_{2}$ emitted in spring and summer for red maple (Acer rubrum) trees at Harvard Forest $(n=4)$ and Bartlett Experimental Forest $(n=5)$

\begin{tabular}{|c|c|c|c|c|c|c|c|c|}
\hline \multirow[b]{2}{*}{ Sample ID } & \multicolumn{2}{|l|}{ Tree ring cellulose } & \multicolumn{2}{|l|}{ Stemwood sugar } & \multicolumn{2}{|l|}{ Spring stem $\mathrm{CO}_{2}$} & \multicolumn{2}{|c|}{ Summer stem $\mathrm{CO}_{2}$} \\
\hline & $\mathrm{F}^{14} \mathrm{C}$ & $\delta^{13} \mathrm{C}(\%)$ & $\mathrm{F}^{14} \mathrm{C}$ & $\delta^{13} \mathrm{C}(\%)$ & $\mathrm{F}^{14} \mathrm{C}$ & $\delta^{13} \mathrm{C}(\% \mathrm{oo})$ & $\mathrm{F}^{14} \mathrm{C}$ & $\delta^{13} \mathrm{C}(\%)$ \\
\hline Harvard-2 & 1.4614 & -22.8 & 1.0993 & -29.1 & 1.0470 & -24.9 & 1.0300 & -24.0 \\
\hline Harvard-3 & 1.2830 & -25.6 & 1.0880 & -28.9 & 1.0486 & -26.3 & 1.0386 & -23.0 \\
\hline Harvard-4 & 1.1405 & -27.4 & 1.0944 & -29.5 & 1.0470 & -25.4 & 1.0325 & -25.8 \\
\hline Harvard-5 & 1.0959 & -24.3 & 1.0587 & -27.7 & 1.0401 & -22.9 & 1.0404 & -22.4 \\
\hline Harvard mean & $1.2452(0.1647)$ & $-25.0(2.0)$ & $1.0851(0.0182)$ & $-28.8(0.8)$ & $1.0457(0.0038)$ & $-24.9(1.4)$ & $1.0354(0.0049)$ & $-23.8(1.5)$ \\
\hline Bartlett-1 & 1.3092 & -27.7 & 1.1226 & -30.6 & 1.0450 & -24.9 & 1.0300 & -24.0 \\
\hline Bartlett-2 & 1.1702 & -28.6 & 1.0888 & -29.6 & 1.0392 & -26.3 & 1.0386 & -23.0 \\
\hline Bartlett-3 & 1.0959 & -25.7 & 1.0495 & -26.9 & 1.0424 & -25.4 & 1.0325 & -25.8 \\
\hline Bartlett-4 & 1.3666 & -24.6 & 1.1145 & -28.2 & 1.0412 & -22.9 & 1.0404 & -22.4 \\
\hline Bartlett-5 & 1.1199 & -24.8 & 1.0747 & -28.0 & 1.0515 & -24.9 & 1.0300 & -24.0 \\
\hline Bartlett mean & $1.2123(0.1194)$ & $-26.3(1.8)$ & $1.0900(0.0297)$ & $-28.7(1.4)$ & $1.0439(0.0048)$ & $-25.5(2.2)$ & $1.0381(0.0166)$ & $-24.4(1.2)$ \\
\hline Mean & $1.2270(0.1327)$ & $-25.7(1.9)$ & $1.0878(0.0239)$ & $-28.7(1.1)$ & $1.0447(0.0042)$ & $-25.2(1.8)$ & $1.0369(0.0121)$ & $-24.1(1.3)$ \\
\hline
\end{tabular}

The measurement precision ( \pm 1SD) for all $\mathrm{F}^{14} \mathrm{C}$ is $\leq 0.0024$ and for $\delta^{13} \mathrm{C}$ values is $\leq 0.15 \%$. For site and global means, values in parentheses indicate \pm 1 SD. Both sites located in New England, USA.
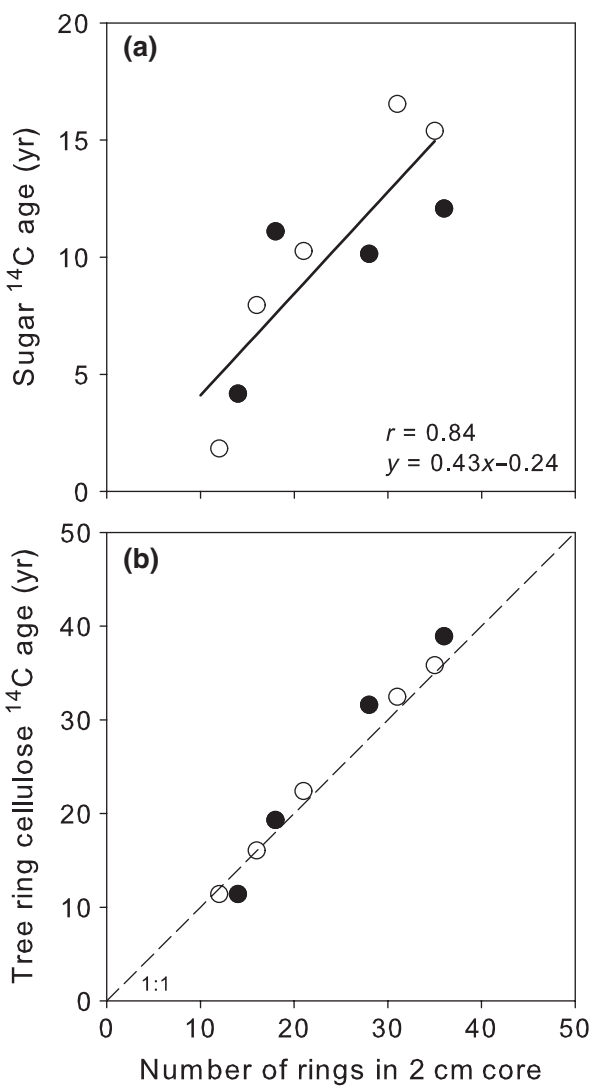

Fig. 2 (a) The linear relationship between the number of rings in the $2-\mathrm{cm}$ stemwood core and the ${ }^{14} \mathrm{C}$ age (yr) of the sugar extracted from the same core for $(n=4)$ red maple (Acer rubrum) trees at Harvard Forest (closed circles) and ( $n=5)$ trees at Bartlett Experimental Forest (open circles), both sites located in New England, USA. (b) The relationship between the number of rings in the $2-\mathrm{cm}$ stemwood core and the ${ }^{14} \mathrm{C}$ age (yr) of the cellulose from the innermost ring (oldest) in the same core for $(n=4)$ red maple trees at Harvard Forest (closed circles) and $(n=5)$ trees at Bartlett Experimental Forest (open circles). The dashed line is the one to one line. component 1 . Component 2 explained an additional $20 \%$ of the total variance in the dataset, and distinguished between the oldest trees $(>100 \mathrm{yr})$ with lower metabolism and younger trees $(c$. $65 \mathrm{yr}$ ) with higher metabolism. In addition to being older, trees with positive scores on component 2 had lower stemwood NSC concentrations, lower stem $\mathrm{CO}_{2}$ flux rates and older stemwood sugars relative to trees with negative scores on this component.

The ring width autocorrelation analysis indicated substantial carry-over or memory effects from year to year, with significant correlation in lagged ring widths of up to $3 \mathrm{yr}$ for the mean ring width of all 36 trees (Fig. 4a). Furthermore, trees with longer growth memory (i.e. an autocorrelation function with longer statistically significant lags) tended to have smaller and older NSC. Thus, the maximum significant lag ( $x$ axis) was negatively correlated with the NSC concentration $(y$ axis, Fig. 4b; $r=-0.27$, $P=0.10$, slope $=-3.21 \pm 0.52$, intercept $=32.36 \pm 2.24$; coefficient estimates $\pm 1 \mathrm{SE}$ via reduced major axis regression and 1000 bootstraps) and positively correlated with sugar ${ }^{14} \mathrm{C}$ age ( $y$ axis, Fig. 4c; $\quad r=0.33, \quad P=0.04, \quad$ slope $=2.54 \pm 0.40, \quad$ intercept $=1.52 \pm 1.74$; coefficient estimates $\pm 1 \mathrm{SE}$ via reduced major axis regression and 1000 bootstraps). Together, these relationships were significant with a multiple linear regression $(r=0.40, \quad P=0.05, \quad$ maximum significant $\quad \mathrm{lag}=3.78 \pm$ $2.81+0.12 \pm 0.13 \times$ sugar ${ }^{14} \mathrm{C}$ age $-0.07 \pm 0.01 \times \mathrm{NSC}$ concentration). Comparable results were obtained when the ring widths were detrended with more flexible splines and not detrended at all. More flexible splines resulted in shorter maximum significant lags in the autocorrelation function. The individual tree correlations with maximum significant lag and NSC age and concentration were in the same direction, but differed in significance (Supporting Information Table S1).

\section{Stump sprouts}

The $\mathrm{F}^{14} \mathrm{C}$ of newly emerged stump sprouts was $1.0507 \pm 0.0044$ $(n=10)$ at Harvard Forest and $1.0931 \pm 0.0238 \quad(n=7)$ at 


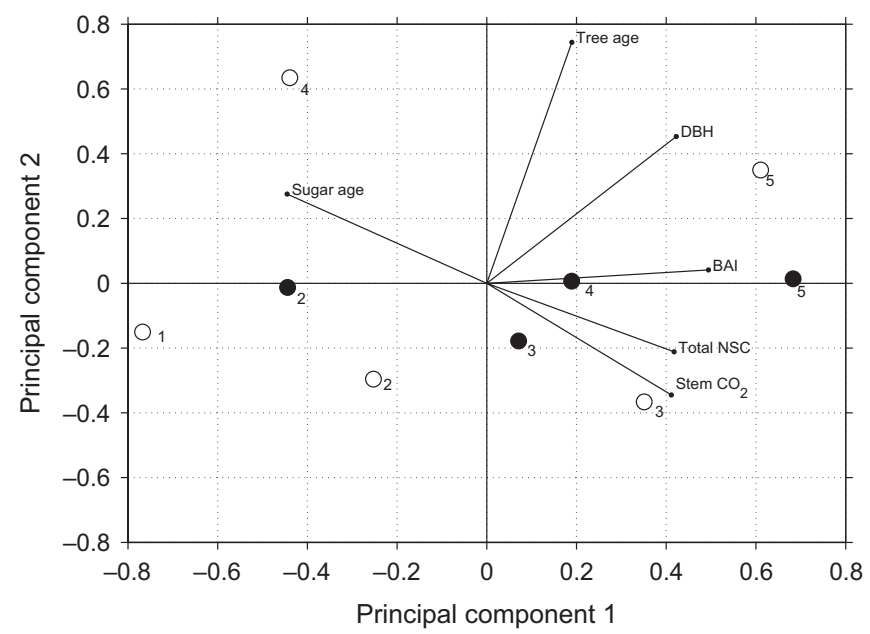

Fig. 3 Biplot of the two principal axes of the principal component analysis performed on tree characteristics for $(n=4)$ red maple (Acer rubrum) trees at Harvard Forest (closed circles) and $(n=5)$ trees at Bartlett Experimental Forest (open circles), both sites located in New England, USA. Vectors indicate the contribution of each variable (tree age, diameter at breast height (DBH), mean basal area increment (BAI), total nonstructural carbon (NSC) concentration, stem $\mathrm{CO}_{2}$ flux rate and sugar age) to the principal components 1 and 2. Numbers identify individual trees and correspond to sample IDs in Tables 1 and 2.

Bartlett Experimental Forest, corresponding to ${ }^{14} \mathrm{C}$ ages of $2.0 \pm 1 \mathrm{yr}$ and $11.1 \pm 4 \mathrm{yr}$, respectively (mean $\pm 1 \mathrm{SD}$, Fig. 1 , Table 3). Trees from which sprouts were collected were much younger at Harvard Forest $(46 \pm 17 \mathrm{yr})$ than at Bartlett Experimental Forest $(81 \pm 32 \mathrm{yr})$. Individual sprout NSC ages ranged from 1 to $17 \mathrm{yr}$, and were strongly related to the age of the tree from which the sprout grew $(x=$ tree age, $y=$ sprout age, slope $=0.18 \pm 0.03$, intercept $=-5.52 \pm 2.29$; coefficient estimates $\pm 1 \mathrm{SE}$ via reduced major axis regression and 1000 bootstraps; $r=0.72, P<0.01)$. Sprout biomass $\delta^{13} \mathrm{C}$ ranged from $-22.0 \%$ to $-28.5 \%$, and was related to both the stump diameter $(r=0.78, P<0.001)$ and tree age $(r=0.74, P<0.001)$, consistent with the observed relationship between stemwood sugar $\delta^{13} \mathrm{C}$ and tree $\mathrm{DBH}$.

\section{Discussion}

\section{Implications for NSC model representations}

Collectively, our results support model representations of NSC storage and allocation that incorporate the following characteristics. The NSC storage pool accumulates with time as the tree becomes larger and older. The NSC storage pool includes both fast (younger) and slow (older) cycling subpools, with exchange between the two. In terms of allocation, there is preferential use of newer NSC (fast pool) for day-to-day metabolism and growth. However, the older NSC (slow pool) remains accessible to the tree given other physiological constraints.

Our previous model of NSC (Richardson et al., 2013) distinguished between fast and slow cycling NSC, with the fast pool supporting metabolism and growth, and transfer from the fast to slow pools occurring in proportion to the gradient between the two pools. The fast pool varied in size on seasonal time scales in response to the balance between supply and demand. At the ecosystem scale, the total NSC pool was constrained to have an MRT of $10 \mathrm{yr}$. The fast pool was estimated to have an MRT of $<1 \mathrm{yr}$, meaning that the slow pool had an MRT $>20 \mathrm{yr}$. Our new data are consistent with this structure, which we apply here to represent the $\mathrm{C}$ dynamics of individual trees in a conceptual model (Fig. 5). In this framework, vigorous trees (Fig. 5a) have a larger, but very dynamic, fast pool, with substantial inputs from new photosynthates, and (essentially) unidirectional transfer from the fast to the slow pool. The age of NSC in the fast pool is $<1 \mathrm{yr}$ because it is flushed out regularly: large inputs and outputs, and thus fast turnover. The age of the NSC in the slow pool increases only slowly over time, because the addition of new photosynthates to this pool keeps it comparatively young. By contrast, trees of low vigor (Fig. 5b) have a smaller fast pool, fewer new inputs from photosynthates and bidirectional transfers between the slow and fast pool. The age of NSC in the fast pool is $>1 \mathrm{yr}$, because new inputs are minimal, and there is contribution from the slow pool. The age of NSC in the slow pool of low vigor trees increases over time, because of minimal new inputs and slow draw-down of the total NSC pool. In the discussion below, we illustrate how our results are consistent with these concepts.

\section{Stemwood NSC pool}

Extracted stemwood sugars were, on average, a decade old (Richardson et al., 2013). The PCA indicated that, among trees, the larger and more vigorous red maples had higher stemwood NSC concentrations and comparatively younger stemwood sugars than smaller and less vigorous trees. This suggests that the more vigorous trees add more new photosynthates to the existing NSC pool each year and rely less on stored NSC for growth and metabolism (i.e. large, fast pool), consistent with the results of ring autocorrelation which show smaller memory effects and our conceptual model (Fig. 5). By contrast, trees with lower vigor add less new photosynthates each year (smaller fast pool) and draw to a larger degree on stored (on average, older, slow pool) NSC for growth and metabolism.

\section{Allocation to metabolism}

Overall, NSC used for metabolism was much younger than the extracted stemwood sugars. The $\mathrm{CO}_{2}$ emitted by the stems was, on average, $1-2 \mathrm{yr}$ old in the spring and $<1 \mathrm{yr}$ old in the summer, whereas stemwood sugars were $10 \mathrm{yr}$ old. This suggests a seasonal shift in the balance of new and old NSC being used for respiratory substrate. However, different combinations of substrate ages could result in the observed ages. For example, the NSC used in spring may be the products of photosynthesis from 1-3 yr previously, a mixture of mostly last year's photosynthesis and a small amount of decade-old NSC, or some other combination. Nevertheless, the change in the $\delta^{13} \mathrm{CO}_{2}$ emitted by the stem provides further evidence of a seasonal shift in respiratory substrate, with greater contribution of more negative $\delta^{13} \mathrm{C}$ substrates in spring before leaf-out and less negative 

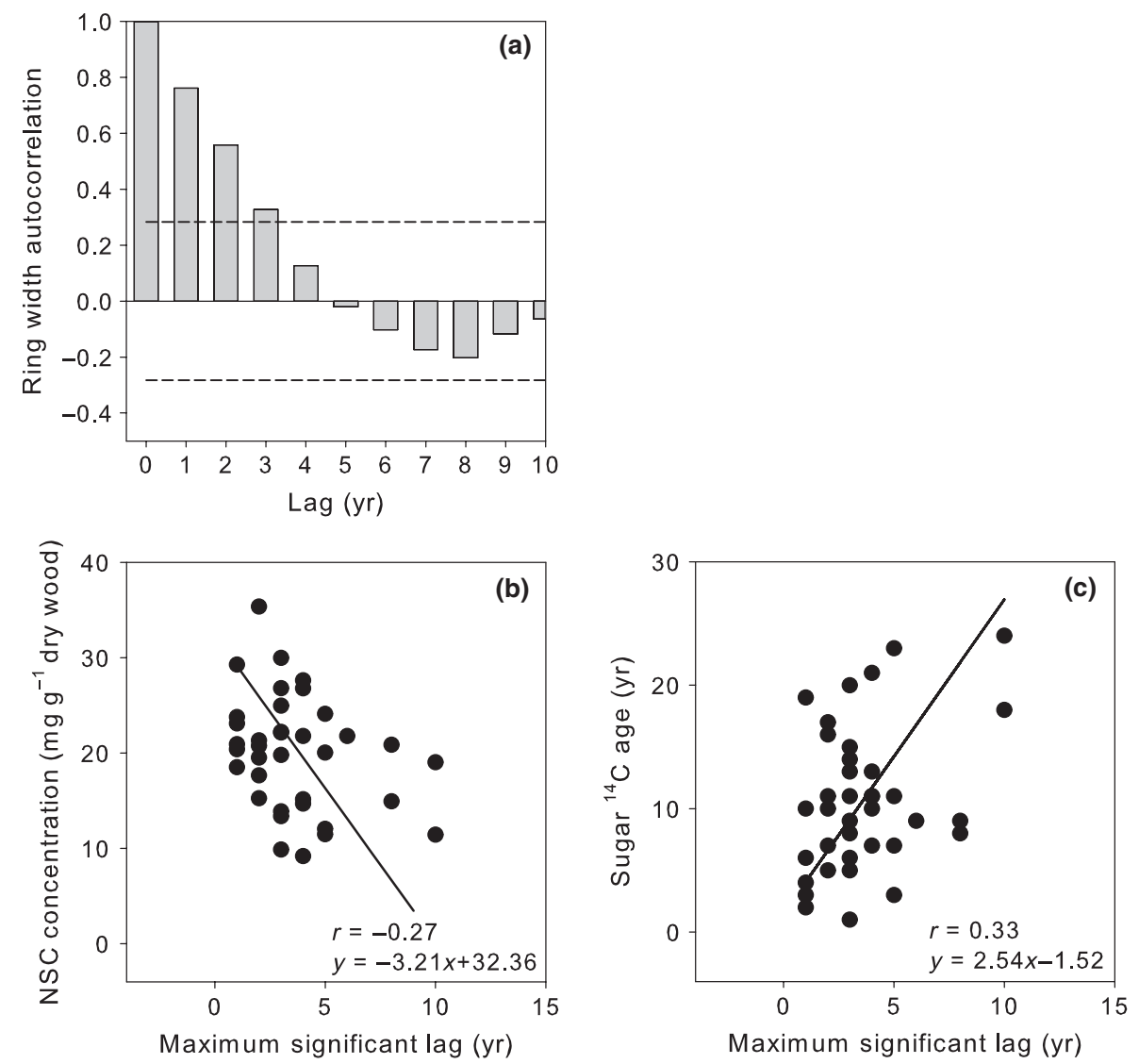

Fig. 4 Autocorrelation function for detrended mean ring width (a), with the mean ring width calculated across $(n=36)$ red maple (Acer rubrum) trees. The dashed lines show the cutoff for coefficients significantly different from zero at 95\% confidence. Relationship between the maximum significant lag time (yr) for each tree from the autocorrelation analysis of ring width with nonstructural carbon (NSC) concentration (mg g ${ }^{-1}$ dry wood) (b) and sugar ${ }^{14} \mathrm{C}$ age (yr) extracted from that tree's stemwood (c).

Table 3 Tree stump diameter $(\mathrm{cm})$, tree stump age (yr), sprout biomass $\mathrm{F}^{14} \mathrm{C}$ (in Fraction Modern) and sprout biomass $\delta^{13} \mathrm{C}(\%)$ for red maple $($ Acer rubrum) at Harvard Forest $(n=10)$ and Bartlett Experimental Forest $(n=7)$

\begin{tabular}{|c|c|c|c|c|}
\hline Site & Stump diameter $(\mathrm{cm})$ & Tree stump age (yr) & Sprout $\mathrm{F}^{14} \mathrm{C}$ & Sprout $\delta^{13} \mathrm{C}(\%)$ \\
\hline Harvard & 3.7 & 35 & 1.0475 & -27.9 \\
\hline Harvard & 10.0 & 33 & 1.0472 & -28.5 \\
\hline Harvard & 15.0 & 37 & 1.0453 & -27.9 \\
\hline Harvard & 15.4 & 33 & 1.0493 & -25.2 \\
\hline Harvard & 18.0 & 45 & 1.0601 & -27.4 \\
\hline Harvard & 18.5 & 52 & 1.0516 & -24.8 \\
\hline Harvard & 18.7 & 35 & 1.0481 & -26.7 \\
\hline Harvard & 27.0 & 42 & 1.0498 & -25.9 \\
\hline Harvard & 33.8 & 56 & 1.0549 & -26.9 \\
\hline Harvard & 66.0 & 88 & 1.0536 & -24.8 \\
\hline Harvard mean & $22.6(17.3)$ & $45.6(16.9)$ & $1.0507(0.0044)$ & $-26.6(1.4)$ \\
\hline Bartlett & 6.8 & 23 & 1.0687 & -27.8 \\
\hline Bartlett & 7.5 & - & 1.0987 & -27.2 \\
\hline Bartlett & 36.0 & 70 & 1.0655 & -23.7 \\
\hline Bartlett & 36.0 & 93 & 1.1193 & -23.8 \\
\hline Bartlett & 39.0 & 115 & 1.0773 & -22.7 \\
\hline Bartlett & 46.0 & 90 & 1.1257 & -24.2 \\
\hline Bartlett & 64.0 & 97 & 1.0968 & -22.0 \\
\hline Bartlett mean & $33.6(20.5)$ & $81.3(32.0)$ & $1.0931(0.0238)$ & $-24.5(2.2)$ \\
\hline Mean & $27.1(18.9)$ & $59.0(28.9)$ & $1.0682(0.0262)$ & $-25.7(2.0)$ \\
\hline
\end{tabular}

The measurement precision ( \pm 1SD) for all $\mathrm{F}^{14} \mathrm{C}$ is $\leq 0.0022$ and for $\delta^{13} \mathrm{C}$ values is $\leq 0.15 \%$. For site and global means, values in parentheses indicate \pm 1 SD. Both sites located in New England, USA.

$\delta^{13} \mathrm{C}$ in the late growing season. Both of these results are consistent with 'last in, first out' dynamics proposed by Lacointe et al. (1993), in which the most recent NSC assimilated is the most accessible, and thus the first to be used. They are also consistent with the two-pool structure described in Richardson et al. (2013). 
(a) High vigor

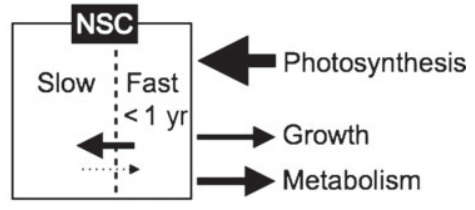

(b) Low vigor

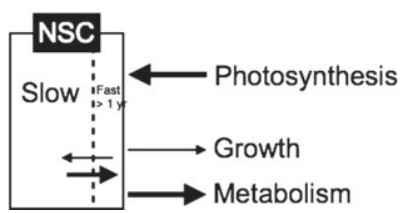

Fig. 5 Conceptual model of nonstructural carbon (NSC) pool dynamics in individual red maple (Acer rubrum) trees of high vigor (a) and low vigor (b). Box and arrow sizes are roughly proportional to the size of the pools and fluxes, respectively. In the vigorous trees, the fast pool is larger, and has a mean age of $<1 \mathrm{yr}$ as a result of greater new photosynthetic inputs. In the low vigor trees, the fast pool is small, and has a mean age of $>1 \mathrm{yr}$, because of minimal new inputs, and transfer from the slow pool to the fast pool.

\section{Allocation to growth}

Similar to the NSC allocated to metabolism, the NSC allocated to ring growth was also much younger than the extracted stemwood sugars. The NSC used to make tree ring cellulose was, on average, $<1$ yr old, supporting previous work which indicated that stored NSC from one growing season is allocated to wood growth in the following year (Kagawa et al., 2006; Richardson et al., 2013). At the same time, the persistent autocorrelation of tree ring widths indicates strong control of growth processes by internal $\mathrm{C}$ dynamics. The relationships between the maximum significant lag in the ring width autocorrelation function and the size of the NSC pools and ${ }^{14} \mathrm{C}$ age of stemwood sugars are exciting, and novel evidence for the important role of stored NSC in mediating ecological memory (i.e. carryover effects in tree growth; Rocha etal., 2006). However, it is clear that, even in trees with the longest memory, rings are still being formed from comparatively recent, and not decade-old, stored NSC. Our results show that trees with larger and younger NSC pools have less carryover (more recently stored NSC contribution to tree ring cellulose growth) and weaker (or shorter) ring width autocorrelation functions (i.e. vigorous trees with large fast pools; Fig. 5a). These relationships between growth and NSC may also be influenced by different factors, such as wood anatomy (diffuse vs ring porous), plant functional type (deciduous vs conifer), plant strategies (fast or slow growing), ecological history and/or climate, and would be exciting to test in other tree species or across environmental gradients.

Finally, autocorrelation in tree ring records has been acknowledged previously as a major challenge to the derivation of accurate climate proxies (Hughes et al., 1982); the results presented here suggest that finer temporal resolution proxies might be obtained from individuals or species with comparatively younger NSC pools (or larger fast NSC pools). Vigorous trees with larger/ younger NSC pools should be more tightly regulated by climate (e.g. temperature extremes, soil moisture or drought, growing season length, etc.) relative to low vigor trees, for which growth is restricted by other persistent limitations (e.g. suppression by competition or nutrient deficiencies, etc.).

\section{Availability of stored NSC}

The NSC remobilized from the root systems to grow stump sprouts proves that decade-old (and older) NSC is available to the tree for new growth when necessary. We did not measure the age of extracted NSC in the roots of these trees, and therefore do not know how it compares (younger, older or similar) with the NSC remobilized to form the sprouts. However, when standardizing the measurements for tree age (using the regression between tree age and sprout age), the age of NSC used to make sprouts is the same as that of the extracted stemwood sugars, suggesting that $10 \mathrm{yr}$ is a reasonable estimate of the mean age of accessible NSC in red maple. Understanding how the concentration and age of NSC varies across the different components (i.e. roots, stems, branches) of the tree and within these components (i.e. radially across xylem rings and coarse roots) would be of great value. This information would improve whole-tree NSC size and age budgets, and help to elucidate how much, and how quickly, the mixing of new and stored NSC occurs within the tree (both vertically and radially across rings). Such measurements might clarify why the extracted stemwood sugar ${ }^{14} \mathrm{C}$ age is related to, but substantially younger than, the number of rings over which we sampled (Fig. 2a).

It is not clear what factors may influence and trigger the use of older stored NSC pools. The trees from which the stump sprouts were collected may not have had any physiological impediment to the remobilization of stored NSC, which may not always be the case. For example, in a previous study, we found that paper birch (Betula papyrifera Marsh.) trees gradually declining in growth over 10 yr retained substantial unused NSC (starch) in the outer stemwood even after they died (Richardson et al., 2013). This is in contrast with a more severe and abrupt trigger, such as complete stem harvest (this study) or hurricane disturbance (Vargas et al., 2009), in which older NSC was found to be accessible. Both hydraulic failure (McDowell et al., 2008) and stress-related impairment of NSC remobilization and long-distance transport (Sala et al., 2010) have been identified as mechanisms that could limit the accessibility of stored NSC to specific tissues. However, the nature and magnitude of the physiological challenge required to access older stored NSC are unknown, and information on this will help us to understand and model tree responses to a range of stresses and ecological conditions, such as release from suppression, wound response, disease, pests and climate change.

\section{Tree size and the NSC pool}

We observed two important relationships between tree size and NSC. First, NSC concentrations were greater in larger trees, supporting previous work by Woodruff \& Meinzer (2011) and the hypothesis that stored NSC plays an important role in maintaining hydraulic conductivity as trees become taller (Sala etal., 2012). These forests have not experienced major drought recently (approximately the last $40 \mathrm{yr}$ ), but there is evidence of regular 
severe droughts in the last $500 \mathrm{yr}$ (Pederson et al., 2013). Moreover, there are regular summer droughts and freeze-thaw cycles in these ecosystems. The use of sugar solutes to create positive pressures in stems to overcome xylem embolism created by drought and freeze-thaw cycles may be one function of (and reason for) the presence of decade-old NSC in these trees, justifying the cost to maintain NSC within the tree for so long. However, other stress factors, such as late spring frosts (Hufkens et al., 2012) and ice storms (Halman et al., 2011), may also explain the increasing NSC concentrations with height, as large canopy trees are more susceptible to severe damage from such events, and it would be advantageous to maintain a large $\mathrm{C}$ buffer pool for recovery.

The second relationship with tree size observed in this study was with stemwood $\delta^{13} \mathrm{C}-\mathrm{NSC}$ (also observed between tree size and remobilized NSC in stump sprout biomass $\delta^{13} \mathrm{C}$ ). This positive relationship can be explained by the fact that, in larger trees, there is a greater proportion of assimilation from sun-lit leaves which discriminate less than shade leaves (Francey et al., 1985; Ehleringer et al., 1986). This $\delta^{13} \mathrm{C}-\mathrm{NSC}$ pattern could be enhanced further because, near the forest floor, the $\mathrm{CO}_{2}$ concentrations are higher and contain less ${ }^{13} \mathrm{C}$ (more negative $\delta^{13} \mathrm{C}$ ) because of the influence of respiration sources (McDowell et al., 2011). However, we do not believe that this was a major factor in our data, given the well-mixed atmospheric $\mathrm{CO}_{2}$ concentrations at the foliage height of even our smallest trees (http://atmos. seas.harvard.edu/lab/data/nigec-data.html). These results suggest challenges for studies using ${ }^{13} \mathrm{C}$ to partition ecosystem-level autotrophic and heterotrophic respiration sources, as the autotrophic respiration component will reflect these large $\delta^{13} \mathrm{C}$-NSC substrate variations between trees of different sizes.

\section{Conclusions}

This study uniquely compares the NSC used for stem respiration, annual wood growth and regrowth from stump sprouts with the NSC present in the stemwood of red maple, a dominant tree species across most of the eastern USA. Using the ${ }^{14} \mathrm{C}$ 'bomb spike' as a tracer of substrate and age, our data provide new insights into the allocation and storage processes of NSC in mature trees, and how NSC pools and processes should be represented in ecosystem C models. We build on previous work by Richardson et al. (2013), confirming that decade-old NSC pools are present within red maple stemwood. As trees become larger and older, the stemwood NSC pool becomes older as NSC accumulates over time. However, more vigorous trees have, on average, younger NSC pools, reflecting greater new photosynthetic inputs. NSC from previous years buffers ring growth and dormant season stem respiration; however, younger stored NSC sources and new NSC sources, when available, are preferentially used. The degree of memory in tree ring growth is related to both the size and age of stemwood NSC, suggesting that NSC pool dynamics may influence inter-annual tree growth patterns over several years. Finally, the NSC remobilized for the growth of stump sprouts unequivocally proves that these decade-old and older NSC pools can be accessible to trees. We conclude that NSC plays an ecologically important role in tree growth and metabolic processes over years to decades, and thus is essential for the understanding and prediction of terrestrial C-cycle responses to global change.

\section{Acknowledgements}

The Milton Fund at Harvard University supported this work. M.S.C. was supported by the National Center for Ecological Analysis and Synthesis, a center funded by the National Science Foundation (NSF) (Grant no. EF-0553768). We thank J. Muhr for the use of the chambers, and S. Djuricin, W. Young and N. Huntington for their assistance in the laboratory. We thank the USDA Forest Service for permission to conduct research in the White Mountain National Forest, and acknowledge the logistical support provided by $\mathrm{T}$. Wagner and R. Alimi. We thank J. O'Keefe and the Harvard Forest Woods Crew for their assistance with field collections.

\section{References}

Abrams MD. 1998. The red maple paradox. BioScience 48: 355-364.

Bloemen J, McGuire MA, Aubrey DP, Teskey RO, Steppe K. 2013. Transport of root-respired $\mathrm{CO}_{2}$ via the transpiration stream affects aboveground carbon assimilation and $\mathrm{CO}_{2}$ efflux in trees. New Phytologist 197: 555-565.

Carbone MS, Czimczik CI, McDuffee KE, Trumbore SE. 2007. Allocation and residence time of photosynthetic products in a boreal forest using a low-level ${ }^{14} \mathrm{C}$ pulse-chase labeling technique. Global Change Biology 13: 466-477.

Carbone MS, Still CJ, Ambrose AR, Dawson TE, Williams AP, Boot CM, Schaeffer SM, Schimel JP. 2011. Seasonal and episodic moisture controls on plant and microbial contributions to soil respiration. Oecologia 167: 265-278.

Carbone MS, Trumbore SE. 2007. Contribution of new photosynthetic assimilates to respiration by perennial grasses and shrubs: residence times and allocation patterns. New Phytologist 176: 124-135.

Chapin FS, Schulze ED, Mooney HA. 1990. The ecology and economics of storage in plants. Annual Review of Ecology and Systematics 21: 423-447.

Czimczik CI, Trumbore SE, Carbone MS, Winston GC. 2006. Changing sources of soil respiration with time since fire in a boreal forest. Global Change Biology 12: 957-971.

Ehleringer JR, Field CB, Lin ZF, Kuo CY. 1986. Leaf carbon isotope and mineral-composition in subtropical plants along an irradiance cline. Oecologia 70: 520-526.

Epron D, Bahn M, Derrien D, Lattanzi FA, Pumpanen J, Gessler A, Hogberg P, Maillard P, Dannoura M, Gerant D et al. 2012. Pulse-labelling trees to study carbon allocation dynamics: a review of methods, current knowledge and future prospects. Tree Physiology 32: 776-798.

Francey RJ, Gifford RM, Sharkey TD, Weir B. 1985. Physiological influences on carbon isotope discrimination in huon pine (Lagarostrobos franklinii). Oecologia 66: 211-218.

Fritts HC. 1976. Tree rings and climate. London, UK: Academic Press.

Garcia D. 2010. Robust smoothing of gridded data in one and higher dimensions with missing values. Computational Statistics \& Data Analysis 54: $1167-1178$.

Gaudinski JB, Torn MS, Riley WJ, Swanston C, Trumbore SE, Joslin JD, Majdi H, Dawson TE, Hanson PJ. 2009. Use of stored carbon reserves in growth of temperate tree roots and leaf buds: analyses using radiocarbon measurements and modeling. Global Change Biology 15: 992-1014.

Halman JM, Schaberg PG, Hawley GJ, Hansen CF. 2011. Potential role of soil calcium in recovery of paper birch following ice storm injury in Vermont, USA. Forest Ecology and Management 261: 1539-1545.

Herms DA, Mattson WJ. 1992. The dilemma of plants - to grow or defend. Quarterly Review of Biology 67: 283-335. 
Hoch G, Richter A, Körner C. 2003. Non-structural carbon compounds in temperate forest trees. Plant, Cell \& Environment 26: 1067-1081.

Hoch G, Siegwolf RW, Keel S, Körner C, Han Q. 2013. Fruit production in three masting tree species does not rely on stored carbon reserves. Oecologia 171: 653-662.

Högberg P, Högberg MN, Göttlicher SG, Betson NR, Keel SG, Metcalfe DB, Campbell C, Schindlbacher A, Hurry V, Lundmark T et al. 2008. High temporal resolution tracing of photosynthate carbon from the tree canopy to forest soil microorganisms. New Phytologist 177: 220-228.

Holmes RL. 1983. Computer assisted quality control in tree-ring dating and measurement. Tree Ring Bulletin 43: 69-78.

Hufkens K, Friedl MA, Keenan TF, Sonnentag O, Bailey A, O'Keefe J, Richardson AD. 2012. Ecological impacts of a widespread frost event following early spring leaf-out. Global Change Biology 18: 2365-2377.

Hughes MK, Kelly PM, Pilcher JR, LaMarche VC. 1982. Climate from tree rings. Cambridge, MA, USA: Cambridge University Press.

Ichie T, Igarashi S, Yoshida S, Kenzo T, Masaki T, Tayasu I. 2013. Are stored carbohydrates necessary for seed production in temperate deciduous trees?. Journal of Ecology 101: 525-531.

Kagawa A, Sugimoto A, Maximov TC. 2006. ${ }^{13} \mathrm{CO}_{2}$ pulse-labelling of photoassimilates reveals carbon allocation within and between tree rings. Plant, Cell \& Environment 29: 1571-1584.

Keel SG, Siegwolf RTW, Jaggi M, Körner C. 2007. Rapid mixing between old and new $\mathrm{C}$ pools in the canopy of mature forest trees. Plant, Cell \& Environment 30: 963-972.

Keel SG, Siegwolf RTW, Körner C. 2006. Canopy $\mathrm{CO}_{2}$ enrichment permits tracing the fate of recently assimilated carbon in a mature deciduous forest. New Phytologist 172: 319-329.

Körner C. 2003. Carbon limitation in trees. Journal of Ecology 91: 4-17.

Krepkowski J, Gebrekirstos A, Shibistova O, Bräuning A. 2013. Stable carbon isotope labeling reveals different carry-over effects between functional types of tropical trees in an Ethiopian mountain forest. New Phytologist 199: 441-451.

Kuptz D, Fleischmann F, Matyssek R, Grams TEE. 2011. Seasonal patterns of carbon allocation to respiratory pools in 60-yr-old deciduous (Fagus sylvatica) and evergreen (Picea abies) trees assessed via whole-tree stable carbon isotope labeling. New Phytologist 191: 160-172.

Lacointe A, Kajji A, Daudet FA, Archer P, Frossard JS. 1993. Mobilization of carbon reserves in young walnut trees. Acta Botanica Gallica 140: 435-441.

Leavitt SW, Danzer SR. 1993. Method for batch processing small wood samples to holocellulose for stable-carbon isotope analysis. Analytical Chemistry 65: $87-89$.

Levin I, Hammer S, Kromer B, Meinhardt F. 2008. Radiocarbon observations in atmospheric $\mathrm{CO}_{2}$ : determining fossil fuel $\mathrm{CO}_{2}$ over Europe using Jungfraujoch observations as background. Science of the Total Environment 391: 211-216.

McDowell N, Pockman WT, Allen CD, Breshears DD, Cobb N, Kolb T, Plaut J, Sperry J, West A, Williams DG et al. 2008. Mechanisms of plant survival and mortality during drought: why do some plants survive while others succumb to drought? New Phytologist 178: 719-739.

McDowell NG, Bond BJ, Dickman LT, Ryan MG, Whitehead D. 2011. Relationships between tree height and carbon isotope discrimination. In: Meinzer FC, Dawson TE, Lachenbruch B, eds, Size-and age-related changes in tree structure and function, Vol. 4. New York, USA: Springer, 255-286.

McGarigal K, Cushman S, Stafford S. 2000. Multivariate statistics for wildlife and ecology research. New York, NY, USA: Springer-Verlag.

Millard P, Grelet GA. 2010. Nitrogen storage and remobilization by trees: ecophysiological relevance in a changing world. Tree Physiology 30: 1083-1095.

Millard P, Sommerkorn M, Grelet G-A. 2007. Environmental change and carbon limitation in trees: a biochemical, ecophysiological and ecosystem appraisal. New Phytologist 175: 11-28.

Muhr J, Angert A, Juárez RN, Muñoz WA, Kraemer G, Chambers JQ,

Trumbore SE. 2013. Carbon dioxide emitted from live stems of tropical trees is several years old. Tree Physiology. doi:10.1093/treephys/tpt049.

Pederson N, Bell AR, Cook ER, Lall U, Devineni N, Seager R, Eggleston K, Vranes KP. 2013. Is an epic pluvial masking the water insecurity of the greater New York City region? Journal of Climate 26: 1339-1354.

Reimer PJ, Brown TA, Reimer RW. 2004. Discussion: reporting and calibration of post-bomb ${ }^{14} \mathrm{C}$ data. Radiocarbon 46: 1299-1304.
Richardson AD, Carbone MS, Keenan TF, Czimczik CI, Hollinger DY, Murakami P, Schaberg PG, Xu XM. 2013. Seasonal dynamics and age of stemwood nonstructural carbohydrates in temperate forest trees. New Phytologist 197: 850-861.

Rocha AV. 2013. Tracking carbon within the trees. New Phytologist 197: 685-686.

Rocha AV, Goulden ML, Dunn AL, Wofsy SC. 2006. On linking interannual tree ring variability with observations of whole-forest $\mathrm{CO}_{2}$ flux. Global Change Biology 12: 1378-1389.

Sala A, Piper F, Hoch G. 2010. Physiological mechanisms of drought-induced tree mortality are far from being resolved. New Phytologist 186: 274-281.

Sala A, Woodruff DR, Meinzer FC. 2012. Carbon dynamics in trees: feast or famine? Tree Physiology 32: 764-775.

Schuur EAG, Trumbore SE. 2006. Partitioning sources of soil respiration in boreal black spruce forest using radiocarbon. Global Change Biology 12: 165-176.

Southon J, Santos G, Druffel-Rodriguez K, Druffel E, Trumbore S, Xu XM, Griffin S, Ali S, Mazon M. 2004. The Keck Carbon Cycle AMS laboratory, University of California, Irvine: initial operation and a background surprise. Radiocarbon 46: 41-49.

Stokes MA, Smiley TL. 1968. An introduction to tree-ring dating. Chicago, IL, USA: University of Chicago Press.

Stuiver M, Polach HA. 1977. Reporting of ${ }^{14} \mathrm{C}$ data - discussion. Radiocarbon 19: 355-363.

Trumbore S. 2006. Carbon respired by terrestrial ecosystems - recent progress and challenges. Global Change Biology 12: 141-153.

Trumbore SE, Angert A, Kunert N, Muhr J, Chambers JQ. 2013. What's the flux? Unraveling how $\mathrm{CO}_{2}$ fluxes from trees reflect underlying physiological processes. New Phytologist 197: 353-355.

Vargas R, Trumbore SE, Allen MF. 2009. Evidence of old carbon used to grow new fine roots in a tropical forest. New Phytologist 182: 710-718.

Wargo PM, Minocha R, Wong BL, Long RP, Horsley SB, Hall TJ. 2002. Measuring changes in stress and vitality indicators in limed sugar maple on the Allegheny Plateau in north-central Pennsylvania. Canadian Journal of Forest Research-Revue Canadienne de Recherche Forestiere 32: 629-641.

Wiley E, Helliker B. 2012. A re-evaluation of carbon storage in trees lends greater support for carbon limitation to growth. New Phytologist 195: 285-289.

Wong BL, Baggett KL, Rye AH. 2003. Seasonal patterns of reserve and soluble carbohydrates in mature sugar maple (Acer saccharum). Canadian Journal of Botany-Revue Canadienne de Botanique 81: 780-788.

Woodruff DR, Meinzer FC. 2011. Water stress, shoot growth and storage of non-structural carbohydrates along a tree height gradient in a tall conifer. Plant, Cell \& Environment 34: 1920-1930.

Würth MKR, Pelaez-Riedl S, Wright SJ, Körner C. 2005. Non-structural carbohydrate pools in a tropical forest. Oecologia 143: 11-24.

Xu X, Trumbore S, Zheng S, Southon J, McDuffee K, Luttgen M, Liu J. 2007. Modifying a sealed tube zinc reduction method for preparation of AMS graphite targets: reducing background and attaining high precision. Nuclear Instruments and Methods in Physics Research Section B: Beam Interactions with Materials and Atoms 259: 320-329.

\section{Supporting Information}

Additional supporting information may be found in the online version of this article.

Table S1 The sensitivity of the autocorrelation analyses of $(n=36)$ trees at Harvard Forest, Bartlett Experimental Forest and Howland Forest to different tree ring width detrending approaches

Please note: Wiley Blackwell is not responsible for the content or functionality of any supporting information supplied by the authors. Any queries (other than missing material) should be directed to the New Phytologist Central Office. 